\title{
Uwarunkowania skuteczności terapii utrwalonego jąkania w opiniach logopedów i studentów logopedii
}

Determinants of the Effectiveness of Persistent Stuttering Therapy in the Opinions of Speech-Language Therapists and SLT Students

\author{
Słowa kluczowe: jąkanie utrwalone, logopedzi, studenci logopedii, skuteczność, terapia \\ Keywords: persistent stuttering/stammering, speech-language therapists (SLTS), SLT students, effectiveness, \\ therapy/treatment
}

\section{Wprowadzenie}

Jąkanie jest zaburzeniem wielowymiarowym, dlatego zarówno proces diagnozy, jak i terapii wymagają zindywidualizowanego, kompleksowego podejścia [Yaruss, Coleman, Quesal, 2012; American Speech-Language-Hearing Association, 2016a; Vanryckeghem, 2018]. Wdrażanie kompleksowej diagnozy, a w konsekwencji budowanie holistycznego obrazu sytuacji klienta/pacjenta ${ }^{1}$, jego doświadczeń związanych z jąkaniem oraz poten-

\footnotetext{
* Szkoła Podstawowa nr 2 im. Stanisława Szymańskiego z Oddziałami Przedszkolnymi, ul. Niedziałkowskiego 21, 42-400 Zawiercie, e-mail: p.o.skrzypiec@gmail.com, ORCID: https://orcid.org/0000 -0002-7698-8276.

** Uniwersytet Śląski, Instytut Językoznawstwa, pl. Sejmu Śl. 1, 40-032 Katowice, e-mail: katarzyna.wesierska@us.edu.pl,kwesierska@centrumlogopedyczne.com.pl, ORCID: https://orcid.org/0000 -0001-6378-9350.

*** University of Warwick, Department of Psychology, University Road, Coventry, CV4 7AL, United Kingdom, e-mail: marta.wesierska@warwick.ac.uk, ORCID: https://orcid.org/0000-0003-4047-9629. 1 Dla opisania osoby z jąkaniem, która korzysta z terapii logopedycznej, w tekście naprzemiennie używa się określeń klient lub pacjent. Zdaniem autorek obie te nazwy mają w przypadku interwencji
} 
cjalnych zasobów i możliwości, jest możliwe dzięki wykorzystaniu modelu ICF (International Classification of Functioning, Disability and Health) rekomendowanego przez Światową Organizację Zdrowia [World Health Organization, 2001; 2009]. Scott Yaruss i Robert Quesal, którzy dokonali adaptacji tego modelu dla jąkania, akcentują potrzebę uwzględniania zarówno potencjału osoby oraz zasobów tkwiących w jej środowisku, jak i negatywnego wpływu zaburzenia na życiową aktywność jednostki zmagającej się z jąkaniem i jej uczestniczenie w różnych formach życia społecznego [Yaruss, 1998; 2007; Yaruss, Quesal, 2004; 2006]. W artykule prezentującym uaktualnioną wersję modelu ICF dla jąkania podkreślono, że - aby lepiej definiować złożoną i zindywidualizowaną naturę tego zaburzenia - należy opierać się nie tylko na obserwacjach słuchaczy, ale przede wszystkim na doświadczeniach osób, które zmagają się z jąkaniem [Tichenor, Yaruss, 2019]. Fundamentalne znaczenie dla jakości interwencji logopedycznej ma zatem uwzględnianie wpływu zaburzenia na jakość życia osoby, która doświadcza tego zjawiska [Klompas, Ross, 2004; Craig, Blumgart, Tran, 2009; Ścibisz, Węsierska, 2019].

Takie kompleksowe postrzeganie jąkania jest w światowej logopedii coraz szerzej akceptowane, coraz bardziej upowszechnia się też wielowymiarowe traktowanie terapii jąkania. Postuluje się zatem, by interwencja logopedyczna w jąkaniu obejmowała nie tylko pomoc klientowi w radzeniu sobie z prymarnymi - behawioralnymi objawami zaburzenia (takimi jak zakłócenia płynności w mowie). Równie istotne jest, by wsparcie logopedyczne obejmowało przepracowywanie w terapii wtórnych atrybutów tego zjawiska, takich jak lęk, strach przed jąkaniem, kwestie unikania, zagadnienia związane $\mathrm{z}$ autostygmatyzacją oraz brakiem poczucia pewności siebie i brakiem samoakceptacji. Najogólniej ujmując, w terapii jąkania utrwalonego wyróżnia się dwa główne nurty: kształtowanie płynności mówienia, określane też mianem mówienia bardziej płynnego, oraz modyfikacja jąkania, znana także jako jąkanie bardziej płynne [Guitar, Peters, 2014; Jankowska-Szafarska, 2018; Manning, DiLollo, 2018; Chęciek, Bażański, 2020].

Metoda terapii jąkania polegająca na uczeniu technik kształtowania płynności mówienia wiąże się z globalnym modyfikowaniem sposobu, w jaki wypowiada się osoba $\mathrm{z}$ jąkaniem. Jest to podejście behawioralne, silnie ustrukturyzowane, którego głównym założeniem jest stopniowe wypracowywanie i automatyzowanie nawyków związanych z upłynnianiem mowy, za pomocą których dąży się do eliminacji jąkania. Uzyskanie płynności mówienia osiąga się poprzez ćwiczenia, początkowo w sytuacjach gabinetowych (emocjonalnie łatwych), a następnie coraz bardziej naturalnych. Ich celem jest automatyzowanie kontrolowanej płynności mówienia poprzez wykorzystywanie pozytywnych wzmocnień. Niewielki nacisk kładzie się tutaj na redukcję reakcji unikania czy na osiąganie zmian w nastawieniu do siebie i swojej mowy. W myśl założeń tej metody takie zmiany postaw mogą wystąpić jako efekt uboczny procesu terapeutycznego.

logopedycznej w jąkaniu pewne ograniczenia. Z jednej strony słowo klient może kojarzyć się marketingowo - z kimś, kto jest interesantem czy korzysta z usług. Z kolei bardziej empatyczne słowo pacjent niepotrzebnie medykalizuje proces terapii logopedycznej w jąkaniu. 
W podejściu polegającym na modyfikacji jąkania pacjenta zachęca się do otwartego i łatwego jąkania. Celem nie jest całkowite wyeliminowanie jąkania, ale wyposażenie klienta w umiejętności pozwalające na skuteczne radzenie sobie z nim i przejęcie kontroli nad własną mową, bez potrzeby zmiany całego nawykowego sposobu wypowiadania się. Główny nacisk kładzie się na zmianę postaw i przekonań wobec mówienia i jąkania (w tym zaakceptowanie faktu bycia osobą z jąkaniem), praca terapeutyczna koncentruje się, zwłaszcza na początku, na czynnikach kognitywnych i afektywnych, odczulaniu i budowaniu wiary w siebie oraz motywacji do podejmowania wyzwań związanych z terapią. Restrukturyzacja poznawcza, która dokonuje się w ramach wdrażania tej metody terapii, nie działa bezpośrednio na objawy behawioralne obecne w mowie pacjenta. W podejściu tym zwraca się uwagę na uczucia jednostki i wewnętrzne reakcje na jąkanie, które mają priorytetowe znaczenie dla powodzenia terapii. Istotne jest to, że w pracy nad czynnikami behawioralnymi logopeda pomaga klientowi w opanowywaniu strategii modyfikacji epizodów zająknięć. Długoterminowe zmiany w strukturach poznawczych (np. pewność siebie, zmiana stosunku do jąkania) wymagają czasu, jednak mogą potencjalnie wywierać długoterminowy, pozytywny wpływ na jednostkę.

W literaturze przedmiotu w ostatnich latach coraz częściej podkreśla się, że zgodnie z regułami praktyki opartej na dowodach (evidence-based practice -EBP) nie można podać jednego uniwersalnego podejścia, które byłoby odpowiednie dla każdej jąkającej się osoby, że w interwencji terapeutycznej w jąkaniu nie da się wszystkim przypisać tej samej terapii [Bernstein Ratner, 2005]. W związku z tym w interwencji logopedycznej w jąkaniu upowszechnia się stosowanie kombinacji różnych podejść - tzw. terapii zintegrowanych (hybrydowych) [Bloodstein, Bernstein Ratner, 2008]. Możliwe jest wówczas realizowanie różnorodnych celów $\mathrm{z}$ użyciem różnych form terapeutycznych, technik i strategii. Włącza się do nich, oprócz klasycznych strategii logopedycznych, elementy podejść wywodzących się z psychoterapii, takich jak na przykład terapia uważności (mindfulness), terapia akceptacji i zaangażowania (Acceptance and Commitment Therapy - ACT), terapia kognitywno-behawioralna (Cognitive Behavioral Therapy - CBT) czy terapia krótkoterminowa skoncentrowana na rozwiązaniu (Solution Focused Brief Therapy - SFBT). W terapii zintegrowanej cele są stale ewaluowane i dopasowywane do bieżących potrzeb pacjenta, obejmują całe spektrum zjawisk związanych $\mathrm{z}$ wielowymiarowością jąkania. W związku z tym, oprócz nabywania nowych umiejętności związanych z upłynnianiem mówienia lub modyfikowaniem jąkania, z klientem pracuje się także nad: wspieraniem proaktywnej postawy wobec wdrażania zmian w sposobie mówienia, dobrym zrozumieniem całej złożoności zjawiska jąkania, w tym dążeniem do akceptacji siebie jako osoby $\mathrm{z}$ jąkaniem. Istotnymi celami $\mathrm{w}$ tak kompleksowo ujmowanych podejściach terapeutycznych są także: zarządzanie stresem i lękiem związanymi z jąkaniem i mówieniem, podejmowanie tzw. eksperymentów behawioralnych, czyli praktykowanie wyuczonych technik w realnych sytuacjach, zwiększenie pewności siebie w sytuacji 
mówienia, dokonywanie przeobrażeń w środowisku jąkającej się osoby, rozumiane jako modyfikowanie postaw wobec jąkania. Najważniejszym celem jest wzmacnianie poczucia sprawczości u pacjenta i budowanie gotowości do stawania się swoim własnym terapeutą, a przede wszystkim niwelowanie wpływu jąkania na jego jakość życia [Manning, DiLollo, 2018].

Praktyka oparta na dowodach jest zalecana jako najbardziej etyczna i skuteczna forma praktyki logopedycznej [Bernstein Ratner, 2005; American Speech-Language-Hearing Association, 2012; 2016b; Papir-Bernstein, 2018]. Z jednej strony EBP jest integracją wyników aktualnych i rzetelnych badań naukowych z doświadczeniami klinicznymi logopedy, a z drugiej akcentuje uwzględnianie opinii, potrzeb i przekonań klienta/pacjenta. W odniesieniu do osoby terapeuty oznacza to jego gotowość do jak najpełniejszego wykorzystania swoich zdolności, kompetencji i umiejętności, a także wcześniejszych doświadczeń zawodowych, posiadanej specjalistycznej wiedzy w celu identyfikowania opóźnień rozwojowych, zaburzeń lub dysfunkcji, by mogła być zastosowana jak najodpowiedniejsza forma interwencji logopedycznej. Jednocześnie niezwykle silnie akcentowany jest trzeci filar EBP - klient/pacjent $\mathrm{z}$ jego osobistymi przekonaniami, potrzebami, oczekiwaniami, które wnosi do procesu interwencji logopedycznej. Martine Vanryckeghem, podnosząc kwestię efektywności interwencji logopedycznej w utrwalonym jąkaniu, podkreśla potrzebę uwzględniania wytycznych EBP w całym procesie interwencji logopedycznej. Zwraca uwagę, że odnosi się to zarówno do diagnozy, jak i programowania procesu terapii, jej wdrażania, a także dokonywania reewaluacji hipotez diagnostycznych i wprowadzania ewentualnych korekt procesu terapeutycznego [Vanryckeghem, Węsierska, 2019].

W rozważaniach nad skutecznością procesu interwencji logopedycznej w jąkaniu, oprócz podkreślania potrzeby stosowania zindywidualizowanego i kompleksowego podejścia do terapii, coraz częściej akcentuje się znaczenie tzw. czynników wspólnych (common factors). Termin ten, wywodzący się z badań prowadzonych początkowo na gruncie psychoterapii, odnosi się do uzyskanych w ich toku wyników. Badania polegały na dokonaniu metaanalizy skuteczności różnych podejść psychoterapeutycznych, stosowanych między innymi w leczeniu depresji, fobii czy schizofrenii. $Z$ niewielkimi wyjątkami badania ujawniły istnienie nielicznych istotnych statystycznie różnic między bardzo odmiennymi podejściami psychoterapeutycznymi. Oznacza to, iż sposoby terapii konkretnego zaburzenia, mimo że wykorzystują różne strategie lub formy w jej procesie, w rezultacie przynoszą podobne efekty. Sformułowano zatem hipotezę o istnieniu wspomnianych już czynników wspólnych dla wszystkich terapii, które ułatwiają osiąganie zmian w procesie interwencji terapeutycznej. Akcentuje się, że to podobieństwa, a nie różnice między terapiami są czynnikami wpływającymi na skuteczność wybranych form psychoterapii [zob. np. Wampold i wsp., 1997; Duncan i wsp., 2010]. Podobieństwa te można podzielić na cztery czynniki lub elementy, które są wspólne dla wszystkich form psychoterapii. Są to: 
- technika (czynniki lub „strategie” unikalne dla różnych metod terapeutycznych);

- zmienne pozaterapeutyczne (takie jak cechy pacjenta i jego środowiska);

- relacja terapeutyczna (cechy terapeuty i klienta, a także jego rodziny, które ułatwiają dokonywanie się zmian i są obecne niezależnie od podejścia terapeutycznego zastosowanego przez klinicystę, tj. użytej techniki; te składniki obejmują wspólne cele, porozumienie w sprawie metod, środków i zadań w terapii oraz więź emocjonalną pomiędzy uczestnikami tego procesu);

- oczekiwania, nadzieje związane z procesem terapeutycznym (poprawa wynikająca z przekonania pacjenta i/lub terapeuty, że proces terapii pomoże pacjentowi).

Podkreśla się przy tym, że relacja terapeutyczna i zmienne pozaterapeutyczne odgrywają w procesie skuteczności ważniejszą rolę niż zastosowane techniki terapeutyczne czy oczekiwania klienta i terapeuty [Asay, Lambert, 2004]. Badania efektywności behawioralnych form interwencji logopedycznej w jąkaniu wykazały, że różnorodne, oparte na dowodach terapie prowadzą do podobnych pozytywnych zmian i nie sposób wskazać, że jedno podejście jest bardziej skuteczne niż inne [Herder i wsp., 2006].

Rozważając kwestie uwarunkowań skuteczności terapii w jąkaniu, należy zwrócić uwagę na czynniki, które - jak się wydaje - nie były wcześniej szczegółowo analizowane, takie jak jakość relacji między terapeutą a pacjentem czy czynny udział pacjentów i ich rodzin w procesie podejmowania decyzji w terapii [Plexico, Manning, DiLollo, 2010]. Wcześniejsze badania prowadzone wśród logopedów wskazują również, że klinicyści manifestują brak wiary we własne kompetencje w zakresie wdrażania skutecznej terapii jąkania [Cooper, Cooper, 1985; Yaruss, Quesal, 2002; Węsierska, Pakura, 2018]. Celem badania opisanego w tym artykule było sondowanie opinii czynnych zawodowo logopedów i studentów logopedii na temat szeroko pojmowanego zagadnienia uwarunkowań skuteczności terapii jąkania utrwalonego.

\section{Organizacja i przebieg badań własnych}

W badaniu wzięło udział 147 respondentów podzielonych na dwie grupy: logopedów $(N=81)$ i studentów logopedii $(N=66)$. Ankietowani pochodzili z obszaru całej Polski. Badania prowadzono wśród studentów studiów podyplomowych na Uniwersytecie Śląskim i Uniwersytecie Łódzkim oraz wśród logopedów, uczestników studiów neurologopedycznych, podnoszących swoje kompetencje zawodowe na studiach podyplomowych prowadzonych na Uniwersytecie Jagiellońskim i Uniwersytecie Łódzkim, a także logopedów uczestniczących w warsztatach logopedycznych z zakresu jąkania wczesnodziecięcego, zorganizowanych w Katowicach. Większość badanych stanowiły kobiety (99,3\%), w całej badanej grupie ankietowanych był tylko jeden mężczyzna - w grupie studentów. Wiek respondentów przedstawia Tabela 1. 
Tabela 1. Wiek respondentów $(N=147)$

\begin{tabular}{|l|c|c|}
\hline \multicolumn{1}{|c|}{ Wiek } & Logopedzi $(N=81)$ & Studenci $(N=66)$ \\
\hline Poniżej 35. r.ż. & $48,15 \%$ & $62,12 \%$ \\
\hline Między 35. a 45. r.ż. & $33,33 \%$ & $33,33 \%$ \\
\hline Między 46. a 55. r.ż. & $13,58 \%$ & $3,03 \%$ \\
\hline Powyżej 56. r.ż. & $2,47 \%$ & $0,00 \%$ \\
\hline Brak odpowiedzi & $2,47 \%$ & $1,52 \%$ \\
\hline
\end{tabular}

Źródło: opracowanie własne na podstawie badań.

Wśród ankietowanych czynnych zawodowo logopedów ponad połowa $(53,09 \%)$ legitymowała się stażem pracy krótszym niż 5 lat, 14,81\% - od 5 do 10 lat, a 25,93\% - powyżej 10 lat (6,17\% ankietowanych nie udzieliło odpowiedzi na to pytanie).

W opisywanym badaniu zastosowano metodę sondażu diagnostycznego, polegającą na gromadzeniu wiedzy o opiniach i poglądach wybranych zbiorowości na temat określonych zjawisk [Pilch, 1998]. Na potrzeby niniejszego artykułu został opracowany kwestionariusz ankiety, składający się z 21 pytań tematycznych oraz 5 pytań dotyczących danych demograficznych. Kafeterie poszczególnych pytań, czyli zestaw możliwych odpowiedzi, miały charakter odpowiedzi zamkniętych (gotowy i nienaruszalny zestaw odpowiedzi) bądź półotwartych (dodatkowa możliwość inne), a także koniunktywnych (możliwość wyboru kilku odpowiedzi) lub dyskoniunktywnych. Dodatkowo przy większości pytań dodano opcję uzasadnienia odpowiedzi. Zabieg ten zastosowano w celu pozyskania większego spektrum informacji oraz ich zwiększonej rzetelności.

Pytania ankiety, oprócz tych związanych z danymi demograficznymi, dotyczyły wszelkich aspektów mających wpływ na skuteczność terapii jąkania utrwalonego i obejmowały zagadnienia dotyczące diagnozy, terapii, stosowanych metod czy form oraz świadomości logopedów i studentów na temat ich osobistego wpływu na powodzenie działań terapeutycznych. Przy użyciu sondażu diagnostycznego poszukiwano odpowiedzi na wiele pytań szczegółowych związanych z tym zagadnieniem. W badaniu zastosowano schemat pomiarów międzygrupowych - ten sam kwestionariusz został rozdany w obu grupach respondentów (logopedów i studentów logopedii) $\mathrm{w}$ celu zidentyfikowania różnic w udzielanych odpowiedziach pomiędzy tymi grupami. Badania były przeprowadzane grupowo, ankiety rozdawano respondentom w postaci papierowej. Ankietowani zostali poproszeni o wyrażenie ustnej zgody na udział w badaniu i poinformowani o celu badania i możliwości zrezygnowania z udziału w sondażu w dowolnym momencie. Dzięki temu umożliwiono im zadawanie pytań związanych z wdrażanym projektem badawczym. Osoba prowadząca badanie podała również swoje dane kontaktowe $\mathrm{w}$ związku $\mathrm{z}$ dalszymi pytaniami lub wątpliwościami. Respondenci byli proszeni o wypełnienie kwestionariusza przed rozpoczęciem zajęć/warsztatów. Badanie prowadzono w dogodnych warunkach (bez zbędnych czynników rozpraszających). Wypełnienie kwestionariusza zajmowało respondentom średnio około 15-20 minut. 


\section{Wyniki badania}

W badaniu przyjęto, że jednym z istotnych czynników skuteczności logopedy - zgodnie z wytycznymi praktyki opartej na dowodach - jest uwzględnianie perspektywy klienta/pacjenta w procesie interwencji logopedycznej. W związku z tym respondenci zostali poproszeni o udzielenie odpowiedzi na pytanie o to, czy logopeda, formułując cele oraz plan terapii, powinien rozpoznać potrzeby, przekonania i oczekiwania klienta. Na to pytanie twierdząco odpowiedziało 96,3\% logopedów i 89,4\% studentów. Choć analiza chi-kwadrat wykazała brak znaczących statystycznie różnic pomiędzy grupami respondentów w tym pytaniu $\left(\chi^{2}(1)=1,30, p>0,05\right)$, to zaistniały różnice istotne statystycznie pomiędzy tymi dwoma grupami dla podawanych uzasadnień odpowiedzi twierdzącej $\left(\chi^{2}(3)=28,62, p<0,001\right)$. Przykładowe uzasadnienia podawane przez ankietowanych dla rozpoznania perspektywy osoby jąkającej się to:

- wzrost poczucia sprawstwa u klienta (61,55\% logopedów i 44,07\% studentów);

- dopasowanie terapii do indywidualnych potrzeb osoby z jąkaniem $(18,42 \%$ logopedów i 43,30\% studentów);

- zwiększenie skuteczności terapii (15,56\% logopedów i 42,37\% studentów);

- budowanie dobrej relacji terapeutycznej pomiędzy logopedą i pacjentem (21,05\% logopedów i 22,22\% studentów);

- wzrost komfortu/poczucia bezpieczeństwa osoby z jąkaniem (2,56\% logopedów i $13,56 \%$ studentów).

W grupie logopedów, którzy na to pytanie odpowiedzieli przecząco, jako uzasadnienie padło stwierdzenie: „terapeuta wie lepiej”. Studenci, którzy wybrali tę opcję, nie wskazali uzasadnienia swojego wyboru.

Istotne dla rozpoznania opinii sondowanych na temat uwarunkowań skuteczności terapii jąkania było zapytanie ich o cele terapii jąkania chronicznego (respondenci mieli możliwość wyboru kilku odpowiedzi). Logopedzi wskazywali następujące najważniejsze cele terapii:

- poprawa komunikacji (69 wskazań na 81 ankietowanych);

- akceptacja jąkania (50);

- redukcja jąkania (33);

- likwidacja jąkania (5).

W kategorii „inne” dla tej grupy ankietowanych znalazły się natomiast: podniesienie samooceny (3), zaspokojenie bieżących potrzeb (3), zmiana postawy wobec jąkania (2).

Z kolei studenci wskazywali następujące cele:

- poprawa komunikacji (48 wskazań na 66 ankietowanych);

- akceptacja jąkania (48);

- redukcja jąkania (27);

- likwidacja jąkania (15). 
Do kategorii „inne” zaliczono: wyeliminowanie czynnika wywołującego jąkanie (4), zaspokojenie potrzeb (2), podniesienie samooceny (1), zmianę postawy wobec jąkania (1).

Na pytanie o to, czy kompleksowa diagnoza (obejmująca rozpoznanie zachowań behawioralnych i kognitywnych, aspektu afektywnego oraz uwarunkowań środowiskowych) ma wpływ na skuteczność terapii, 85,2\% logopedów odpowiedziało twierdząco (żaden $\mathrm{z}$ ankietowanych nie udzielił negatywnej odpowiedzi na to pytanie, ale $14,09 \%$ nie miało zdania w tej kwestii). Z kolei w grupie studentów odpowiedzi twierdzącej udzieliło 59,1\% (podobnie jak w grupie logopedów nie było przeczących odpowiedzi na to pytanie, ale aż 33,3\% ankietowanych studentów nie miało zdania na ten temat, a 7,6\% respondentów nie udzieliło żadnej odpowiedzi). Odpowiedzi na to pytanie wykazały istnienie różnicy istotnej statystycznie pomiędzy wynikami obu grup respondentów $\left(\chi^{2}(1)=8,63, p=0,003\right)$.

Kolejne zagadnienia, które zostały poddane analizie, dotyczyły najskuteczniejszych podejść stosowanych w interwencji logopedycznej w utrwalonym jąkaniu, a także form terapii oraz kwestii związanych z jej intensywnością. Ankietowani, poproszeni o wskazanie, które z podejść terapeutycznych jest w ich opinii bardziej skuteczne w terapii utrwalonego jąkania, udzielali następujących odpowiedzi:

- modyfikacja jąkania (19,75\% logopedów i 9,09\% studentów);

- kształtowanie płynności mowy (14,81\% logopedów i 19,70\% studentów);

- kombinacja obu tych podejść (59,26\% logopedów i 62,12\% studentów).

Ankietowani mieli również możliwość wybrania opcji „,inne” (1,23\% logopedów i 3,03\% studentów). W przypadku takiego wyboru respondenci zostali poproszeni o rozwinięcie swojej wypowiedzi poprzez wskazanie konkretnych podejść. Różnice w odpowiedziach na to pytanie w obu grupach nie były istotne statystycznie.

Respondentów zapytano również o to, jaka forma terapii jąkania utrwalonego jest najskuteczniejsza. Ankietowani logopedzi i studenci opowiadali się za następującymi formami wdrażania terapii jąkania:

- terapia indywidualna (4,93\% logopedów i $24,24 \%$ studentów);

- terapia grupowa (13,58\% logopedów i 4,55\% studentów);

- kombinacja obu form terapii (62,96\% logopedów i 66,67\% studentów).

Odpowiedzi udzielone w obu grupach respondentów na pytanie o formy terapii różniły się znacząco statystycznie $\left(\chi^{2}(3)=13,12, p=0,004\right)$.

Ankietowani, pytani o wpływ intensywności wdrażanej terapii na jej skuteczność, wyrażali pogląd, że terapia powinna być prowadzona w sposób intensywny, ale ambulatoryjny, na przykład spotkania co tydzień w poradni lub w gabinecie $(77,3 \%$ logopedów i 77,8\% studentów). Inną formę intensywnej terapii - turnusową - wybrało 4,5\% logopedów i 9,9\% studentów. Najrzadziej wybierano terapię prowadzoną w nieregularnych odstępach czasowych - 3\% logopedów i 4,9\% studentów. Odpowiedzi w obu grupach respondentów na pytanie o wpływ intensywności wdrażania terapii nie wykazywały różnic istotnych statystycznie. 
W sondażu rozpoznawano również opinie respondentów na temat wpływu jakości relacji terapeutycznej pomiędzy logopedą i osobą jąkającą się na skuteczność procesu terapeutycznego. Twierdzącej odpowiedzi na to pytanie udzieliło 96,3\% logopedów i 89,40\% studentów. Uzasadnienia respondentów brzmiały przykładowo: „dobry kontakt przekłada się na owocną współpracę”; „dobry kontakt daje poczucie bezpieczeństwa i buduje zaufanie”; „dobry kontakt powoduje wzajemne motywowanie się". Żaden z respondentów nie wybrał odpowiedzi negatywnej, natomiast 3,7\% logopedów oraz 9,09\% studentów nie miało zdania na ten temat.

Ankietowani zostali również poproszeni o udzielenie odpowiedzi na pytanie o wpływ osobowości logopedy na skuteczność terapii. Twierdzącej odpowiedzi na to pytanie udzieliło $86,42 \%$ logopedów i $71,21 \%$ studentów. Tylko 1,24\% czynnych zawodowo logopedów uznało, że osobowość terapeuty nie wpływa na efekty terapii. Niepokoić może natomiast to, że takiej odpowiedzi udzieliło aż 6,06\% studentów. Co więcej, zdania na ten temat nie wyraziło $12,35 \%$ logopedów i aż $21,21 \%$ studentów. Należy zauważyć, że zwłaszcza grupa studentów wydaje się nie doceniać znaczenia refleksyjnego spojrzenia na własną osobowość i ocenienia jej z tej perspektywy.

Nawiązując do roli logopedy w procesie terapeutycznym, respondentów poproszono także o wskazanie najbardziej pożądanych cech, jakimi powinien legitymować się terapeuta. Rysunek 1 prezentuje zestawienie cech pozytywnie wpływających na sukces terapii jąkania utrwalonego (wyniki nie są podane procentowo, ponieważ respondenci mieli możliwość wyboru kilku odpowiedzi).

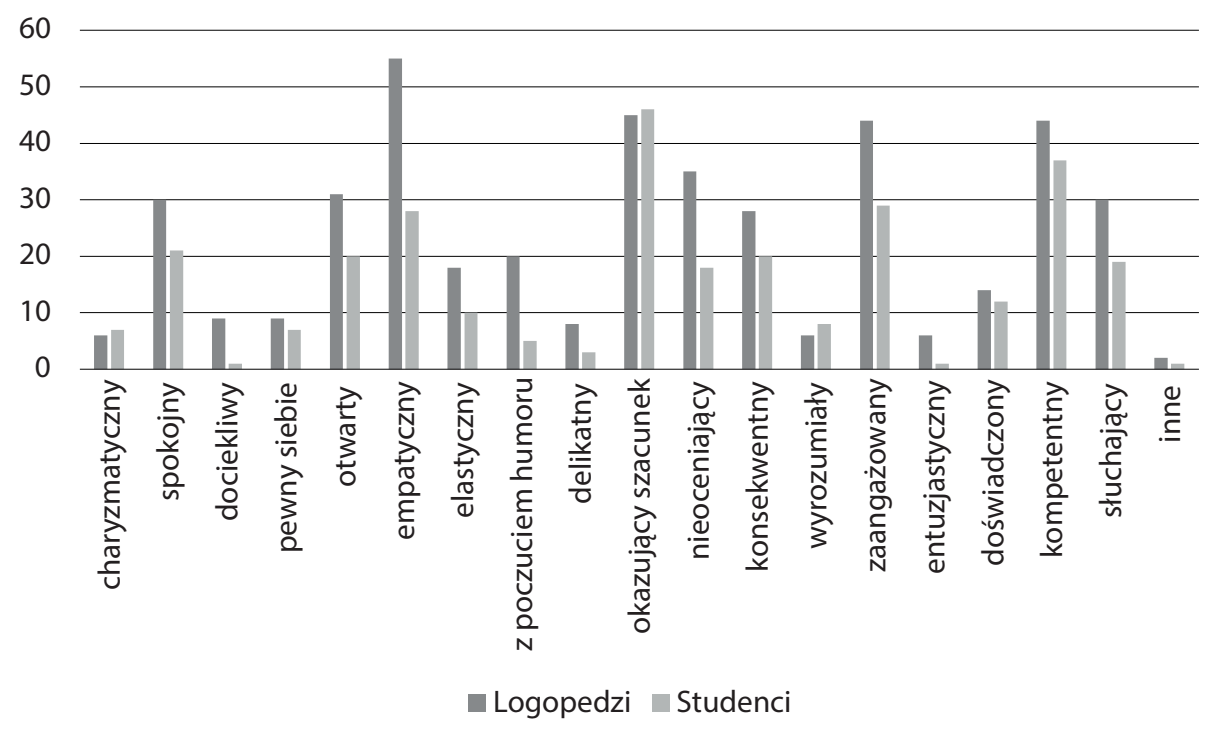

Rysunek 1. Pożądane cechy logopedów zajmujących się terapią jąkania; N = 147

Źródło: opracowanie własne na podstawie badań. 
Respondenci zostali zapytani również o to, czy logopeda powinien stale uzupełniać swoją wiedzę o jąkaniu (np. śledzić aktualne wyniki badań w tym zakresie), aby prowadzona przez niego terapia była skuteczniejsza. Z takim stwierdzeniem zgodziło się 97,53\% logopedów i 87,88\% studentów. Podano następujące uzasadnienia: „rozwój zawodowy specjalisty ma wpływ na prowadzone terapie”, „istnieje możliwość poznawania i nabywania nowych, skuteczniejszych metod pracy”. Żaden z ankietowanych nie udzielił negatywnej odpowiedzi na to pytanie. Zdania na ten temat nie miało 2,47\% logopedów i 6,06\% studentów.

Podobnie większość logopedów $(92,82 \%)$ oraz studentów $(90,91 \%)$ uznała, że doskonalenie zawodowe i podnoszenie swoich kompetencji specjalistycznych w zakresie jąkania wywiera znaczny wpływ na efekty terapii. Różnice pomiędzy grupami nie były znaczące statystycznie $\left(\chi^{2}(1)=0,14, p>0,05\right)$. Jednocześnie warto zwrócić uwagę, że 7,4\% logopedów i aż 9,09\% studentów nie wyraziło swojej opinii w tym zakresie. Zdecydowana większość ankietowanych uznała podnoszenie swoich umiejętności zawodowych za absolutnie konieczne i naturalne, dlatego - być może - $21 \%$ logopedów i 27,3\% studentów stwierdziło, że nie trzeba uzasadniać odpowiedzi. $\mathrm{Ci}$, którzy uargumentowali swój wybór, najczęściej upatrywali pozytywnego wpływu samodoskonalenia nie tylko na terapię, ale także na ich wiarę we własne umiejętności. Wśród uzasadnień pojawiały się też następujące odpowiedzi: „samodoskonalenie polega na zdobywaniu wiedzy, którą wykorzystuje się w pracy”; „samodoskonalenie zwiększa pewność siebie logopedów”; „samodoskonalenie zwiększa możliwości logopedów”. Odpowiadając na pytanie o źródła wiedzy na temat jąkania, logopedzi wskazywali najczęściej: publikacje książkowe (76 wskazań na 81 ankietowanych), czasopisma specjalistyczne (75), strony internetowe (65). Z kolei studenci najczęściej wskazywali czasopisma (63 na 66 ankietowanych), publikacje książkowe (58) i strony internetowe (50). Inne podane przez respondentów źródła to konferencje oraz inni specjaliści.

Ankietowani zostali również poproszeni o wyrażenie opinii na temat tego, czy chcieliby się dokształcać w obszarze zaburzeń płynności mowy (studia, kursy, warsztaty) oraz o doprecyzowanie potencjalnego zakresu tematycznego. Aż 85,2\% logopedów i 69,7\% studentów wyraziło chęć doskonalenia swoich kompetencji z tego zakresu tematycznego. Różnice pomiędzy grupami nie były znaczące statystycznie. Ankietowani podali potencjalne tematy takich szkoleń: jąkanie i giełkot, diagnozowanie jąkania oraz metody terapii i praktyczne aspekty pracy z jąkającymi się osobami.

Respondenci zostali także zapytani o to, czy osoba jąkająca się powinna korzystać z pomocy innych specjalistów, na przykład psychologów, psychoterapeutów, psychiatrów, fizjoterapeutów. Odpowiedzi ankietowanych wskazują na to, że zarówno logopedzi (95,06\%), jak i studenci $(90,91 \%)$ w ogromnej większości oceniają współpracę $\mathrm{z}$ innymi specjalistami w terapii utrwalonego jąkania jako korzystną z punktu widzenia skuteczności terapii. Grupy respondentów nie różniły się znacząco 
statystycznie w odpowiedzi na to pytanie $\left(\chi^{2}(1)=1,28, p>0,05\right)$, jednak różnica pomiędzy uzasadnieniami podawanymi dla tej odpowiedzi okazała się znacząca statystycznie $\left(\chi^{2}(4)=13,07, p=0,011\right)$. Najwięcej logopedów uzasadniało swój wybór następująco: jeżeli logopeda nie jest w stanie sam pomóc klientowi w osiągnięciu postępów, to wskazana jest praca $w$ teamie terapeutycznym. Z kolei wśród uzasadnień podawanych przez studentów znalazło się stwierdzenie, że jąkanie to wieloaspektowe zaburzenie wpływające na wiele sfer życia, dlatego należy posiłkować się wsparciem innych specjalistów. Analizując bardziej szczegółowo uzasadnienia takiej interdyscyplinarnej współpracy w terapii jąkania, można zaobserwować pewną tendencję. O ile logopedzi skupiali się bardziej na osobie jąkającej się i na jej potrzebach, o tyle studenci mocniej akcentowali konieczność pracy w zespole terapeutycznym ze względu na wieloaspektowość i kompleksowość jąkania.

W badaniu analizowano również opinie respondentów na temat wpływu najbliższego środowiska (bliskich osób, np. rodziców, opiekunów, partnera; osób ze środowiska szkolnego, np. nauczycieli; osób ze środowiska pracy, np. współpracowników) na skuteczność terapii. Na to pytanie odpowiedzi pozytywnej udzieliło więcej logopedów $(96,3 \%)$ niż studentów $(87,9 \%)$ i ta różnica była istotna statystycznie $\left(\chi^{2}(2)=8,29\right.$, $p=0,16)$. Nieznaczny odsetek badanych specjalistów $(3,7 \%)$ uznał, że nie ma ono znaczenia dla terapii. Warto zwrócić uwagę, że wśród studentów 9,1\% ankietowanych nie miało zdania na ten temat, taka sytuacja nie zaistniała w przypadku logopedów. Jako uzasadnienie pozytywnych odpowiedzi podano na przykład: „otoczenie mobilizuje i wspiera”; „uświadomione osoby w otoczeniu ułatwiają funkcjonowanie jąkającemu się".

W sondażu padły także pytania o wpływ ruchu samopomocy na skuteczność terapii chronicznego jąkania. Wśród sondowanych zdecydowana większość uznała, że uczestnictwo pacjenta w spotkaniach grup samopomocowych może być skutecznym wsparciem terapii (87,65\% logopedów i $81,82 \%$ studentów). Odpowiedzi na to pytanie podawane w obu grupach respondentów nie różniły się znacząco statystycznie $\left(\chi^{2}(2)=2,80, p>0,05\right)$. Żaden ze studentów nie udzielił negatywnej odpowiedzi na to pytanie, ale taką opcję wybrało 1,24\% logopedów. Natomiast swojego zdania na ten temat nie miało 9,88\% logopedów i 18,18\% studentów. Przykładowe uzasadnienia pozytywnych odpowiedzi podawane przez respondentów to: „grupy wsparcia są formą dodatkowego wsparcia”; „umożliwiają wymianę cennych doświadczeń”; „mogą pozwolić «otworzyć się» klientowi”.

Ankietowani zostali ponadto poproszeni o wyrażenie opinii na temat wpływu autoterapii na skuteczność interwencji terapeutycznej w jąkaniu. Sondowanym wyjaśniono, że autoterapia rozumiana jest przez autorki badania jako gotowość pacjenta do stawania się własnym terapeutą i podejmowania związanych z tym wyzwań, na przykład poprzez samodzielne wyznaczanie sobie nowych celów terapeutycznych, samodzielne aranżowanie sytuacji pozwalających na wdrażanie ćwiczeń czy też uczestnictwo w różnych formach warsztatowych, mających na celu rozwój osobisty. 
Pozytywnej odpowiedzi na to pytanie udzieliło 79,02\% logopedów i $69,64 \%$ studentów. Odpowiedzi udzielane przez logopedów i studentów nie różniły się statystycznie $\left(\chi^{2}(2)=4,54, p>0,05\right)$. Logopedzi najczęściej argumentowali swoje odpowiedzi tym, że autoterapia motywuje klienta do działania i angażuje go w ćwiczenia terapeutyczne. Również studenci, podobnie jak czynni zawodowo logopedzi, najczęściej wskazywali na zaangażowanie oraz motywację, ale dodatkowo wspominali o poczuciu „sprawczości” pacjenta, które występuje podczas autoterapii. Negatywnej odpowiedzi na to pytanie udzieliło 2,48\% logopedów i aż 10,61\% studentów. Warto też zwrócić uwagę, że znaczny odsetek ankietowanych w obu grupach nie miał zdania na ten temat (18,5\% logopedów i 15,2\% studentów). O ile wszyscy logopedzi odpowiedzieli na to pytanie, o tyle $4,5 \%$ studentów nie wybrało żadnej opcji.

Interesująco przedstawiają się odpowiedzi respondentów na pytanie o gotowość do podjęcia pracy z jąkającą się osobą. Twierdzącej odpowiedzi udzieliło zaledwie $34,57 \%$ logopedów oraz $4,55 \%$ studentów i różnica ta jest istotna statystycznie $\left(\chi^{2}(2)=24,21, p<0,001\right)$. Z kolei negatywnej odpowiedzi na to pytanie udzieliło $50,62 \%$ logopedów i 87,88\% studentów. Jako uzasadnienie podawano następujące odpowiedzi: „,brak pewności siebie”; „,nabywam wiedzę”; „,brak wiedzy, doświadczenia". Manifestowanie przez większość studentów braku gotowości do podjęcia pracy z osobami z jąkaniem, jak sami stwierdzili, wynika z faktu nabywania przez nich wiedzy. Znaczna część respondentów biorących udział w tym badaniu uchyliła się od udzielania odpowiedzi na to pytanie, wybierając opcje „nie mam zdania” (uczyniło tak 13,6\% logopedów i 7,6\% studentów).

\section{Podsumowanie}

W artykule zaprezentowano wyniki sondażu diagnostycznego przeprowadzonego w dwóch grupach: czynnych zawodowo logopedów i studentów logopedii. Celem tego badania było rozpoznanie opinii badanych na temat uwarunkowań skutecznej terapii utrwalonego jąkania. Wyniki wskazują, że zarówno ankietowani logopedzi, jak i studenci logopedii uznają, że potrafią przeprowadzić diagnozę jąkania i poprawnie rozpoznać symptomy tego zaburzenia. Co ciekawe, nieco pewniejsi swoich umiejętności w zakresie kompleksowego diagnozowania byli studenci logopedii. Może to wynikać z poprawiającej się jakości kształcenia w zakresie balbutologopedii na uniwersytetach oraz zwiększających się możliwości dostępu do różnych uzupełniających form doskonalenia zawodowego w tym zakresie (np. w ramach studiów podyplomowych, a także podczas konferencji, warsztatów czy kursów). Badani respondenci sygnalizowali, że zdają sobie sprawę z tego, jak ważna dla skuteczności interwencji terapeutycznej w utrwalonym jąkaniu jest kompleksowa diagnoza.

Według większości ankietowanych najważniejszym celem terapii w jąkaniu chronicznym powinno być dążenie do poprawy jakości komunikacji klienta oraz 
do akceptacji jąkania. Pokazuje to, że nie jest już tak rozpowszechniona tendencja do koncentrowania się w terapii na całkowitej likwidacji jąkania, co niegdyś stanowiło nadrzędny cel terapii jąkania. Dla ankietowanych logopedów i studentów ważne było rozpoznanie potrzeb i opinii pacjenta, a - co ważniejsze - liczni respondenci podkreślali, że uważają jego zdanie za istotne dla efektów prowadzonej terapii.

Zarówno logopedzi, jak i studenci, pytani o podejścia, metody i formy terapii wpływające na jej skuteczność, najczęściej wskazywali na rozwiązania hybrydowe, polegające na wprowadzaniu indywidualnej i grupowej terapii oraz łączeniu podejść kształtowania płynności mówienia i modyfikacji jąkania. Respondenci zdecydowanie opowiadali się także za koniecznością systematycznego wdrażania terapii. Czynnikiem wspomagającym terapię, zdaniem logopedów i studentów, jest interdyscyplinarność oddziaływań, na przykład poprzez podejmowanie współpracy z innymi specjalistami, takimi jak psycholog czy psychoterapeuta. Ankietowani, udzielając takich odpowiedzi, uzasadniali je zazwyczaj wielowymiarowością jąkania, które w ich opiniach wywiera wpływ na wiele aspektów życia klienta.

W ocenie respondentów uczestnictwo osób jąkających się w spotkaniach grup samopomocowych i podejmowanie przez pacjenta różnych form aktywności w ramach autoterapii mogą wywierać pozytywny wpływ na proces terapeutyczny. Większość logopedów i studentów uznała uczestnictwo klienta w spotkaniach grup samopomocowych za istotną formę wsparcia, możliwość „otwarcia się” pacjenta bądź okazję do wymiany doświadczeń z innymi uczestnikami dzielącymi podobne doświadczenia. Z kolei autoterapia w opiniach respondentów była najczęściej postrzegana jako czynnik angażujący i motywujący klienta do działania, a dodatkowo dający mu poczucie odzyskiwania kontroli nad własnym życiem, sprawczości - tak istotnej w skutecznej terapii jąkania [Blanchet i wsp., 2020; Jankowska-Szafarska, 2020]. Innym aspektem wpływającym pozytywnie na przebieg i efekty procesu terapii było zaangażowanie najbliższego środowiska, które respondenci uznali za budujące, mobilizujące oraz przede wszystkim wspierające. Podkreślano przy tym rolę akceptujących postaw środowiska wobec jąkania i osoby z jąkaniem.

W badaniu sondowano również poglądy logopedów i studentów dotyczące potencjalnego wpływu osoby terapeuty na efektywność procesu interwencji logopedycznej w jąkaniu. Warto podkreślić, że większość ankietowanych doceniała rolę logopedy oraz znaczenie relacji terapeutycznej klient - logopeda. Najistotniejsze cechy skutecznego balbutologopedy wskazywane najczęściej przez czynnych zawodowo terapeutów to empatyczność, umiejętność okazywania szacunku, kompetencja, zaangażowanie, spokój i otwartość. Z kolei wśród odpowiedzi najczęściej udzielanych przez studentów były następujące cechy terapeuty jąkania: umiejętność okazywania szacunku pacjentowi, kompetencja, zaangażowanie, empatyczność oraz konsekwencja. Ankietowani w obu grupach w zdecydowanej większości wskazywali też na potrzebę stałego poszerzania wiedzy na temat zaburzeń płynności mowy i podnoszenia swoich kompetencji w tym zakresie. 
Z opisanych powyżej wyników wyłania się dość optymistyczny obraz na temat wiedzy i świadomości logopedów oraz studentów logopedii w zakresie uwarunkowań skuteczności utrwalonego jąkania. Na tym tle niepokojąco prezentuje się jednak kwestia gotowości ankietowanych do wdrażania interwencji terapeutycznej w utrwalonym jąkaniu. Fakt, że zaledwie 4,55\% studentów i tylko 34,57\% czynnych zawodowo logopedów uznało, że czują się dobrze przygotowani do podjęcia działań terapeutycznych w tym zakresie, nie może napawać optymizmem. O ile w przypadku studentów ich niezdecydowanie można tłumaczyć tym, że dopiero rozpoczynają swoją karierę zawodową i być może nie mieli możliwości zweryfikowania swojej wiedzy w praktyce, o tyle alarmująca jest sytuacja, w której blisko dwie trzecie ankietowanych logopedów sygnalizuje, że czują się nieprzygotowani do podjęcia pracy z osobami jąkającymi się, uzasadniając to najczęściej zbyt małym doświadczeniem lub brakiem zaufania do swoich kompetencji i umiejętności w tym zakresie. Można postawić tezę, że jest to związane z lękiem logopedów przed skonfrontowaniem się z jąkaniem. Brak gotowości do podejmowania terapii jąkania może się również wiązać z obawą specjalistów, wynikającą z ich zrozumienia złożoności tego zjawiska.

Podsumowując, warto wskazać na wzrastający poziom wiedzy teoretycznej obecnych i przyszłych specjalistów. Daje się przy tym zauważyć potrzebę uzupełnienia wiedzy teoretycznej doświadczeniami praktycznymi, które wpłynęłyby na zwiększenie poczucia posiadania specjalistycznych kompetencji i odpowiednich umiejętności u logopedów i studentów. Warte rozważenia wydaje się wdrażanie różnych form doskonalenia zawodowego, na przykład w postaci e-learningu, mentoringu, coachingu czy z wykorzystaniem superwizji [Rose, Best, Higgs, 2005]. Mimo iż powszechne jest przekonanie, że logopedzi obawiają się pracy z jąkającym się osobami, to opisane w artykule wyniki badań wskazują raczej dość duże zainteresowanie środowiska czynnych zawodowo logopedów i studentów logopedii tematyką dotyczącą zaburzeń płynności mowy. W ocenie autorek ten pozytywny trend może wiązać się z upowszechnianiem w naszym kraju wiedzy na temat opartych na dowodach formach interwencji terapeutycznej w utrwalonym jąkaniu. Pozostaje mieć również nadzieję, że będzie to korelować ze wzrostem liczby logopedów, którzy być może zainteresują się w przyszłości specjalizowaniem się w dziedzinie balbutologopedii, na przykład w ramach Europejskiej Specjalizacji Zaburzeń Płynności Mowy (European Clinical Specialization in Fluency Disorders) ${ }^{2}$.

Należy jednak podkreślić, że wyniki tego badania nie mogą być traktowane jako w pełni reprezentatywne dla wszystkich logopedów i studentów logopedii (m.in. dlatego, że ankietowanymi logopedami byli wyłącznie tacy, którzy brali udział w jakiejś formie doskonalenia zawodowego - studiowali podyplomowo neurologopedię $\mathrm{i} /$ lub brali udział $\mathrm{w}$ warsztatach logopedycznych). Opisane w tym artykule wyniki są uogólnieniem panujących opinii i nie reprezentują poglądów całej populacji tych środowisk.

2 Zob. http://www.ecsf.eu. 


\section{Podziękowania}

Autorki artykułu pragną podziękować dr Ewie Biłas-Pleszak, prof. UŚ, i dr Monice Kaźmierczak z Uniwersytetu Łódzkiego za pomoc w dotarciu do grup respondentów, a także wszystkim osobom, które wyraziły chęć wzięcia udziału w tym badaniu - za poświęcony czas.

\section{Literatura}

American Speech-Language-Hearing Association, 2012, Evidence-based practice (EBP), ASHA, Rockville, http://www.asha.org/members/ebp/ (dostęp: 10.01.2020).

American Speech-Language-Hearing Association, 2016a, Code of ethics. Ethics, http:// www.asha.org/policy/ (dostęp: 10.01.2020).

American Speech-Language-Hearing Association, 2016b, Scope of practice in speech-language pathology [Scope of practice], http://www.asha.org/policy/ (dostęp: 10.01.2020).

Asay T.P., Lambert M.J., 2004, The empirical case for the common factors in therapy: Quantitative findings, [w:] M.A. Hubble, B.L. Duncan, S. D. Miller (red.), The heart \& soul of change, Washington: American Psychological Association, s. 23-55.

Bernstein Ratner N., 2005, Evidence-based practice in stuttering: Some questions to consider, „Journal of Fluency Disorders", t. 30(3), s. 163-188.

Blanchet P., Boroń A., Chmielewski G., Everard R., Haase T., Gładosz Z., Jankowska-Szafarska L., Ravid B., St. Louis K., Węsierska K., 2020, Sukces w terapii jąkania - czym jest i jak go osiagnną́ - opinie „podwójnych ekspertów”, [w:] K. Węsierska, M. Witkowski (red.), Zaburzenia płynności mowy - teoria i praktyka, t. 2, Katowice: Wydawnictwo Uniwersytetu Śląskiego, s. 13-31.

Bloodstein O., Bernstein Ratner N., 2008, A handbook on stuttering, Clifton Park: Thomson/Delmar Learning.

Chęciek M., Bażański E., 2020, Objawy niepłynności mówienia u osób doroslych oraz propozycje terapeutyczne z użyciem strategii „mówienia bardziej płynnego” - studia przypadków, [w:] K. Węsierska, M. Witkowski (red.), Zaburzenia płynności mowy - teoria i praktyka, t. 2, Katowice: Wydawnictwo Uniwersytetu Śląskiego, s. 189-204.

Cooper E.B., Cooper C.S., 1985, Clinician attitudes toward stuttering: A decade of change (1973-1983), „Journal of Fluency Disorders”, t. 10(1), s. 19-33.

Craig A., Blumgart E., Tran Y., 2009, The impact of stuttering on the quality of life of adults who stutter, „Journal of Fluency Disorders”, t. 34(2), s. 61-71.

Duncan B.L., Miller S.D., Wampold B.E., Hubble M.A. (red.), 2010, The Heart and Soul of Change. Delivering What Works in Therapy, Washington: American Psychological Association.

Guitar B., Peters T.J., 2014, Dobór metod terapii jąkania. Przewodnik dla logopedów, Katowice: Centrum Logopedyczne.

Herder C., Howard C., Nye Ch., Vanryckeghem M., 2006, Effectiveness of behavioral stuttering treatment: A systematic review and meta-analysis, „Contemporary Issues in Communication Sciences and Disorders", nr 3, s. 76-81.

Jankowska-Szafarska L., 2018, Praktyczne zastosowanie podejścia modyfikacji jąkania u młodzieży, [w:] K. Węsierska (red.), Zaburzenia płynności mowy, Gdańsk: Harmonia Universalis, s. 224-239.

Jankowska-Szafarska L., 2020, Wzmacnianie poczucia sprawstwa i samoakceptacji w terapii modyfikacji utrwalonego jąkania, [w:] K. Węsierska, M. Witkowski (red.), Zaburzenia płynności mowy - teoria i praktyka, t. 2, Katowice: Wydawnictwo Uniwersytetu Śląskiego, s. 255-265. 
Klompas M., Ross E., 2004, Life experiences of people who stutter, and the perceived impact of stuttering on quality of life: Personal accounts of South African individuals, „Journal of Fluency Disorders", t. 29(4), s. 275-305.

Manning W.H., DiLollo A., 2018, Clinical decision making in fluency disorders, San Diego: Plural Publishing.

Papir-Bernstein W., 2018, The Practitioner's Path in Speech-Language Pathology. The Art of SchoolBased Practice, San Diego: Plural Publishing.

Pilch T., 1998, Zasady badań pedagogicznych, Warszawa: Wydawnictwo Akademickie "Żak”.

Plexico L., Manning W.H., DiLollo A., 2010, Client perceptions of effective and ineffective therapeutic alliances during treatment for stuttering, ,Journal of Fluency Disorders”, t. 35(4), s. 333-354.

Rose M., Best D., Higgs J. (red.), 2005, Transforming Practice through Clinical Education, Professional Supervision, London: Elsevier.

Ścibisz K., Węsierska K., 2019, Jakość życia dorosłych osób z jąkaniem - implikacje dla praktyki logopedycznej / Kvalita života koktavých - implikace pro klinickou praxi, „Listy klinické logopedie", nr 2, s. 80-98.

Tichenor S.E., Yaruss S.J., 2019, Stuttering as Defined by Adults Who Stutter, „Journal of Speech, Language, and Hearing Research", t. 62(12), s. 4356-4369.

Vanryckeghem M., 2018, Wielowymiarowa, oparta na dowodach diagnoza prowadzaca do wielopłaszczyznowej terapii jąkania, [w:] K. Węsierska (red.), Zaburzenia płynności mowy, Gdańsk: Harmonia Universalis, s. 30-43.

Vanryckghem M., Węsierska K., 2019, Praktyka oparta na dowodach $w$ diagnozie i terapii jąkania, „Forum Logopedy”, nr 31, s. 10-16.

Wampold B.E., Mondin G.W., Moody M., Stich F., Benson K., Ahn H.-N., 1997, A meta-analysis of outcome studies comparing bona fide psychotherapies: Empirically, "all must have prizes", „Psychological Bulletin”, t. 122(3), s. 203-215.

Węsierska K., Pakura M., 2018, Sytuacja dorostych zmagajacych się z jąkaniem w Polsce w opiniach logopedów i osób jąkających się, [w:] K. Węsierska (red.) przy współpracy K. Gaweł, Zaburzenia płynności mowy, Gdańsk: Harmonia Universalis, s. 113-130.

World Health Organization, 2001, International classification of functioning, disability and health, Geneva: WHO.

World Health Organization, 2009, Międzynarodowa Klasyfikacja Funkcjonowania Niepetnosprawności i Zdrowia (ICF), Warszawa: Centrum Systemów Informacyjnych Ochrony Zdrowia.

Yaruss J.S., 1998, Real-time analysis of speech fluency: Procedures and reliability training, „American Journal of Speech-Language Pathology", t. 7(2), s. 25-37.

Yaruss J.S., 2007, Application of the ICF in fluency disorders, „Seminars in Speech and Language”, t. 28(4), s. 312-322.

Yaruss J.S., Quesal R.W., 2002, Academic and clinical education in fluency disorders: An update, "Journal of Fluency Disorders", t. 27(1), s. 43-63.

Yaruss J.S., Quesal R.W., 2004, Stuttering and the International Classification of Functioning, Disability, and Health (ICF): An update, „Journal of Communication Disorders”, t. 37(1), s. 35-52.

Yaruss J.S., Quesal R.W., 2006, Overall Assessment of the Speaker's Experience of Stuttering (OASES): Documenting multiple outcomes in stuttering treatment, „Journal of Fluency Disorders”, t. 31(2), s. $90-115$.

Yaruss J.S., Coleman C.E., Quesal R.W., 2012, Stuttering in school-age children: A comprehensive approach to treatment [Letter to the Editor], „Language, Speech, and Hearing Services in Schools", t. 43(4), s. 536-548. 
Streszczenie

W artykule podjęto tematykę uwarunkowań skuteczności terapii jąkania utrwalonego w ocenie logopedów i studentów logopedii. W części teoretycznej zarysowano czynniki wpływające pośrednio i bezpośrednio na skuteczność terapii tego zaburzenia. Podczas badania analizie poddano czynniki mające wpływ na powodzenie terapii jąkania chronicznego. W tym celu wykorzystano metodę sondażu diagnostycznego i użyto autorskiego kwestionariusza ankiety. W badaniu wzięło udział 147 respondentów (81 logopedów oraz 66 studentów logopedii). Wyniki tego projektu badawczego wykazują, że zarówno logopedzi, jak i studenci logopedii dysponują adekwatną wiedzą na temat uwarunkowań terapii jąkania utrwalonego. Ustalono, że według ankietowanych skuteczna terapia wiąże się z zastosowaniem kompleksowej diagnozy, hybrydowych podejść terapeutycznych i różnych form terapii, dostosowanych do indywidualnych potrzeb klienta czy pacjenta. W rezultacie badań ujawniono pozytywny stosunek badanych do autoterapii klienta, jego udziału w spotkaniach grup samopomocowych oraz zaangażowania najbliższego otoczenia w proces wsparcia. Wyniki badania wskazują, że respondenci dostrzegają znaczenie jakości relacji logopeda - klient w procesie terapii. Większość badanych manifestowała jednak duże wątpliwości w związku z własnymi umiejętnościami w zakresie wdrażania terapii jąkania. W podsumowaniu zaakcentowano, że niezależnie od stosunkowo zadowalającego stanu wiedzy na temat terapii jąkania ważne jest rozwijanie umiejętności praktycznych i poczucia kompetencji logopedów i studentów logopedii w tym zakresie. Dodatkowo zwrócono uwagę na rosnące zainteresowanie tematyką zaburzeń płynności mowy.

\section{Abstract}

The article discusses a recent study on the effectiveness of persistent or chronic stuttering therapy based on the opinions of speech-language therapists (SLT's) and SLT students. The purpose of the study was to consider their opinions in light of the conditions of effectiveness. In the theoretical section of the article, factors affecting chronic stuttering therapy are outlined both directly and indirectly. Factors affecting the success of chronic stuttering treatment were analyzed. To achieve the aim of the study a bespoke survey was used. The survey involved 147 respondents (81 SLTs and 66 SLT students). The results of this study show that both SLTs and SLT students have relatively adequate knowledge of the conditions that result in effective stuttering therapy. According to those surveyed, effective therapy is associated with the application of a comprehensive assessment process, the use of hybrid therapeutic approaches and various forms of therapy, as well as its adaptation to the client's individual needs. The study has revealed the positive attitude of the respondents toward the client's self-therapy, his or her participation in self-help group meetings together with the immediate environment's involvement in the support process. The results of the study indicate that the respondents are aware of the impact of the quality of SLT-client relationships on the success of the therapy process. However, most of those surveyed expressed considerable doubts about their own skills in implementing stuttering intervention. 
In the conclusion, the authors highlight that independently from the somewhat satisfactory level of knowledge about stuttering therapy it is important to pay attention to the development of practical competences and the self-confidence of SLTs and SLT students in this relm. Additionally the growing interest in the topic of speech and language disorders was highlighted. 